\title{
Training of Mathematical Disciplines Teachers for Higher Educational Institutions as a Contemporary Problem
}

\author{
Kateryna Vlasenko ${ }^{1}$, Olena Chumak ${ }^{2, *}$, Irina Sitak $^{3}$, Iryna Lovianova $^{4}$, Oksana Kondratyeva $^{5}$ \\ ${ }^{1}$ Department of Higher Mathematics, Donbass State Engineering Academy, Ukraine \\ ${ }^{2}$ Department of General Engineering, Donbas National Academy of Civil Engineering and Architecture, Ukraine \\ ${ }^{3}$ Department of Mathematics and Computer Technologies, the Institute of Chemical Technologies of the East Ukrainian Volodymyr \\ Dahl National University, Ukraine \\ ${ }^{4}$ Department of Mathematics and Methods of Its Training, Kryvy Rih State Pedagogical University, Ukraine \\ ${ }^{5}$ Department of High Mathematics, Cherkasy State Technological University, Ukraine
}

Copyright(C2019 by authors, all rights reserved. Authors agree that this article remains permanently open access under the terms of the Creative Commons Attribution License 4.0 International License

\begin{abstract}
The article describes the problem of preparing a modern teacher of mathematical disciplines for a higher technical educational institution in the system of higher pedagogical and classical education. The modern scientific research focusing on training a highly-qualified mathematics teacher has been analyzed. The results of the questionnaire for mathematics teachers at higher technical education institutions and students studying in 014 'Secondary Education (Mathematics)' specialties are presented. The current state of preparedness of master's degree holders to teach mathematicians at higher technical educational institutions is evaluated. One of the ways to solve the problem is to develop the 'For Higher School Mathematics Teacher' educational platform. The concept of developing this online environment and filling its components with content has been highlighted. The rationale for creating a community of practitioners consisting of teachers of higher technical and pedagogical educational institutions, the cooperation of which should contribute to solving the problem, is provided. The possibilities of using the platform for further training of both young and experienced teachers are considered.
\end{abstract}

Keywords Mathematics Teacher Training, Higher Technical Educational Institution, System of Higher Pedagogical Education, Learning Platform

\section{Introduction}

\subsection{Problem Statement}

The development of global education encourages the modernization of the educational field. Thus, over the past few years, a wave of reforms in higher education has spread in many developed countries, namely the United States, Britain, European countries, Pakistan, Taiwan, China, etc. One of the topical international problems is the shortage of highly qualified Mathematics teachers. And Ukraine makes here no exception. Training of modern Mathematics teachers for Ukrainian higher technical educational institutions (HTEI) is provided by Master's degree programmers. However, the graduates, who get a Master's degree in 014 'Secondary Education (Mathematics) specialty, complain about their inadequate preparedness to teach mathematical disciplines in technical universities. In addition, we may observe the gap between the worked-out methods used by Mathematics teachers at higher educational institutions and the advancements in modern technologies. In particular, this is applied to the technologies that are disseminated via learning platforms. As a result, there is no possibility for both young and experienced teachers at HTEIs to access such online environment that should help in their advanced training and promote their careers in education. This is exactly what predetermines the relevance of studying the problems of finding ways to training and further development for a modern Mathematics teacher at HTEI.

\subsection{Analysis of Recent Research and Publications}

The issues of training teachers for higher educational institutions (HEI) were addressed in works by many scientists, in particular M. Azhar and M. M. Kayani [2], H. C. Çelik and S. Karayaman [6], A. Dorofeev, S. Chirkina, D. Gagloev, T. Savina [8], L. Kyyenko-Romaniuk and L. Zayachkovska [10], Jieyi Li and Chich-Jen Shieh [12], M. 
L. Niess [15], Mary N. Ogawa and Dilmeire S. R. Vosgerau [16], R. Powers and W. Blubaugh [17], B. Saqipi and J. Vogrinc [20], A. Tucker, E. Burroughs, A. Hodge [24], N. Volkova [28] and others.

The majority of the contemporary researchers, namely M. Azhar and M. M. Kayani [2], J. Boaler [4], A.H. Brunauer, T. Deutsch, F. Cankar [5], H. C. Çelik and S. Karayaman [6], F. Quinn [18], D. Saba [19], A. Tucker, E. Burroughs, A. Hodge [24], emphasize the importance of bringing educational changes and developing new ways of professional pedagogical training of a present-day teacher. This is linked to the creation of new Mathematics Standards based on STEM education [13] and Teacher Training Programs from National Math \& Science Initiative [22].

Thus, in order to increase the efficiency of the process of HEI teacher training, some scientists substantiate the expediency of competency-based approach in training. We support the views of A. Dorofeev, S. Chirkina, D. Gagloev, T. Savina [8], B. Saqipi and J. Vogrinc [20], who propose improving the methodological training of a Mathematics teacher at HEI by measuring competencies on the basis of multi-component diagnostics. The scientists point out the lack of knowledge among some teachers about how to encourage students to study. This opinion comes in line with the studies on mathematics teacher training by National Research Council USA headed by J. Kilpatrick, J. Swafford, and B. Findell [14]. The researchers note that although some teachers have learnt mathematics they still don't know how to apply this knowledge in their teaching to help their students learn. Thus, the mathematics they have learned is not well connected to what they teach or they may have no idea how to connect it.

This is also acknowledged by such Ukrainian scientists as M. Vasylieva-Khalatnykova [25], O. Yevsiukov [29], who point out the main shortcomings in training teaching personnel for HTEIs. The scientists put emphasis on the lack of the system of pedagogical, psychological and methodological knowledge that may help in mastering the teaching profession. Besides, the authors underline that it is necessary to take into account the differences in the processes of training Mathematics teachers for HTEI and classical Mathematics teacher. This difference is conditioned by the specifics of teaching Mathematics and its practical content to future specialists in the technical field.

In this connection, B. Cetinkaya, M. Kertil, A. K. Erbas, H. Korkmaz, C. Alacaci and, E. Cakiroglu [7], J. Boaler [4], K. Vlasenko [27] stress the importance of using research projects and project tasks in mathematics while training technical specialties students. There can, therefore, be no doubt that it is the project that provides the student with an understanding of why the course of mathematics is studied at a higher technical school. The scientists substantiate the expediency of free access for graduate students and Mathematics teachers at HTEIs to the methods of projects in mathematics. Moreover, the scientists promote the importance of considering the issue of expanding Mathematics teacher initial and further training outside classroom. According to D. Saba [19], this can be achieved via learning platforms.

This opinion is consistent with the results of the analysis of many current studies on improving the organization of communication between a teacher and a student [21], improving independent and personalized learning [1], [11], enhancing the quality and range of resources [23], improving teaching and learning monitoring [15]. The scientists highlight the need for developing and disseminating digital learning resources, in particular Web-platforms, for higher school Mathematics teachers. The usage of these means has significant advantages and contributes to upgrading the quality of training for teaching Mathematics to technical specialties students.

Consequently, the expediency of modernizing the process of training and further training of Mathematics teachers at HTEIs is in no dispute, but the aspects of solving this problem have not been fully studied.

All the above-mentioned facts are the reason why the objective of the article is to find ways of qualitative training of HTEI mathematical disciplines teachers in the system of higher pedagogical and classical education. Furthermore, the paper presents the description of the concept of developing a learning platform, the use of which can promote further training for both young and experienced teachers.

\section{Materials and Methods}

The research procedure was based on the usage of the following methods and methodologies: questionnaires, surveys, pedagogical observation.

The detection of the main problems and shortcomings in the work of HTEI Mathematics teachers was carried out in the course of the ascertaining stage of the experiment during 2018. At this stage, questionnaires and surveys were conducted among Mathematics teachers at higher educational institutions of Ukraine. 180 Mathematics teachers of all ages were involved in the survey. The length of the respondents' teaching experience ranged from 5 to 35 years. $40 \%$ of the surveyed teachers acquired pedagogical vocational education, $36 \%$ - Classical education. Most teachers hold the position of an Associate Professor, namely $72 \%$. Among the respondents, there were $12 \%$ of teaching assistants, and $12 \%$ of Professors.

The questionnaire consisted of 15 questions and was developed with the help of an open online service and posted on the Internet at https://docs.google.com/forms/d/1ajWwfVnP3Klk_2ngPx SV4U-Vof371DDv5bvIR7AY0MQ/edit?usp=forms_home 


\section{\&ths $=$ true.}

Moreover, in order to identify the shortcomings of training Mathematics teachers for HEIs, the survey among the graduate students in pedagogical and classical higher education institutions of Ukraine was performed. 44 graduate students, studying in 014 'Secondary Education (Mathematics)' specialty, were involved in the questionnaire.

Among the respondents, there were graduate students of Kryvyi Rih State Pedagogical University, Sumy State Pedagogical University named after A. Makarenko, National Pedagogical Dragomanov University, Berdyansk State Pedagogical University, Vinnytsia Mykhailo Kotsiubynskyi State Pedagogical University.

The survey conducted made it possible to evaluate the current state of preparedness of Master's Degree holders to teach Mathematics in higher technical educational institutions. The analysis of the questionnaire outcomes will be provided in the results of the study.

The searching stage of the experiment was started with the analysis of modern scientific studies. The aim of this was to find ways to solve the problem of training a teacher of mathematical disciplines for HTEIs in the system of pedagogical and classical HEIs. The directions for professional development, technical support and resource development to give aid to graduate students mastering teaching activities, as well as HEI teachers, were determined. Among the other ways of efficient training of Mathematics teachers for higher technical educational institutions, the development of a learning platform was chosen. The expediency of developing the platform was pointed out by $76 \%$ of the interviewed HTEI teachers. They mentioned that the existence of such online environment would significantly contribute to their further training. The expediency of developing the platform was also pointed out by $81.8 \%$ of the graduate students. They noted that the accessibility and mobility of the corresponding online environment were an important requirement for a present-day student who learns in the midst of mobile devices.

In response to the demands of the respondents, we launched the 'For Higher School Mathematics Teacher' learning platform in the form of a web-based system consisting of two subsystems: users' subsystem (web site) and administrating subsystem (content management). To be in line with the current trends in the existence of the web-based systems, the online platform meets the following requirements:

- accessibility, reliability and security which involve posting content on a modern, technically equipped server, or hosting;

- data security which involves the use of present-day web development, anti-hacking and anti-malware tools;
- user-friendly adaptive interface which allows the users and administrators to work fast on stationary and mobile devices.

User's materials will be posted in the English and Ukrainian languages. The target users of this platform shall be final year students at higher pedagogical educational institutions and teachers at higher technical educational institutions. The platform should assist each of these groups in solving one of the most difficult issues of the educational process: how to teach and what kind of Mathematics can be taught to a student who is acquiring engineering education. The development of the above-mentioned learning environment enables it to be used anywhere and at any convenient time.

The analysis of the questionnaire results, the proposals from the respondents and the existing educational resources helped to come up with the development environment, platform concept and sections. The concept of developing the platform was discussed at the international scientific and methodological conference 'Problems of Mathematical Education' in Cherkasy [26].

The syllabi posted on the platform will be targeted at online professional training of Maths graduate students. Using the syllabi section will help the teachers to ensure professional development online. The topics of the syllabi involve reviewing of various specialists' opinions on the modernization of mathematical engineering education. Also, the syllabi shall become the main source for continuous improvement of teaching Mathematics to the users.

The review and analysis of the regulatory documents will facilitate the implementation of mathematical reforms and the promotion of opportunities for those students who are on the way of their professional development under the Master's Degree program.

In the mathematical courses section, the platform will offer directions for modernization of mathematical courses and the testing intended to assess students' preliminary knowledge, competencies and learning skills as mathematics teachers.

Bringing the issues of learning motivation into a separate section, we shall review the recent research on motivation for mathematical education. It will be shown how to help students to set achievable goals. Students' achievement of the initial goal will mean their transition to a higher level. Success in achieving their goals on a regular basis will motivate students to strive for more. The section will also point out mathematical skills required for different occupations.

The platform will propose design principles and methodologies of promoting educational innovations that are based on teaching tools and encourage the platform users to reflect on the use of certain technologies for teaching mathematics to students.

What should a project on mathematics be like? This section will help to shift teachers' focus to the essence of 'mathematics for engineers' idea, but not vice versa. In our 
study, considerable attention is paid to the issues of forming professional competencies of technical specialties students. That is the reason why we consider it necessary to involve them in the development of projects on higher mathematics. The efficient use of additional resources and chats will stimulate interest in successful engineering achievements, in particular, in the field of promoting STEM-technologies that help to introduce mathematics into practical engineering research.

To review modern monitoring technologies, the users' will be offered for their consideration those technologies that are computer-based and aimed at teaching planning. Most attention will be given to such technologies, which provide a way for blended learning from personalized models. This approach will take into account the individual learning style of each student. The section will also outline the backbone of some technologies, including Blockchain technology, which is only the beginning to draw the attention of the international educational community.

Teachers' Forum will contribute to such learning that is based on constant feedback between the users and the developers. Interactivity is to promote the development of students' discussion groups. The purpose of this section is also to present the international library of pedagogical practices, the experience of applying STEM technologies by the countries that have achieved greater success in solving this problem. This section will highlight the experience of Ukrainian, European, American, Australian teachers and Asian specialists in the field of education. The insight into the researchers' practical experience will allow for the creation of the practitioners' community and provide support for their willingness to cooperate.

Starting from February 22, 2019, the platform began to operate (Fig. 1) at http://formathematics.com/. The authors and moderators of the platform are the team of lecturers of the Donbass State Engineering Academy, Donbas National Academy of Civil Engineering and Architecture, the Institute of Chemical Technologies (the town of Rubizhne) of the East Ukrainian Volodymyr Dahl National University, Kryvy Rih State Pedagogical University, Cherkasy State Technological University. 


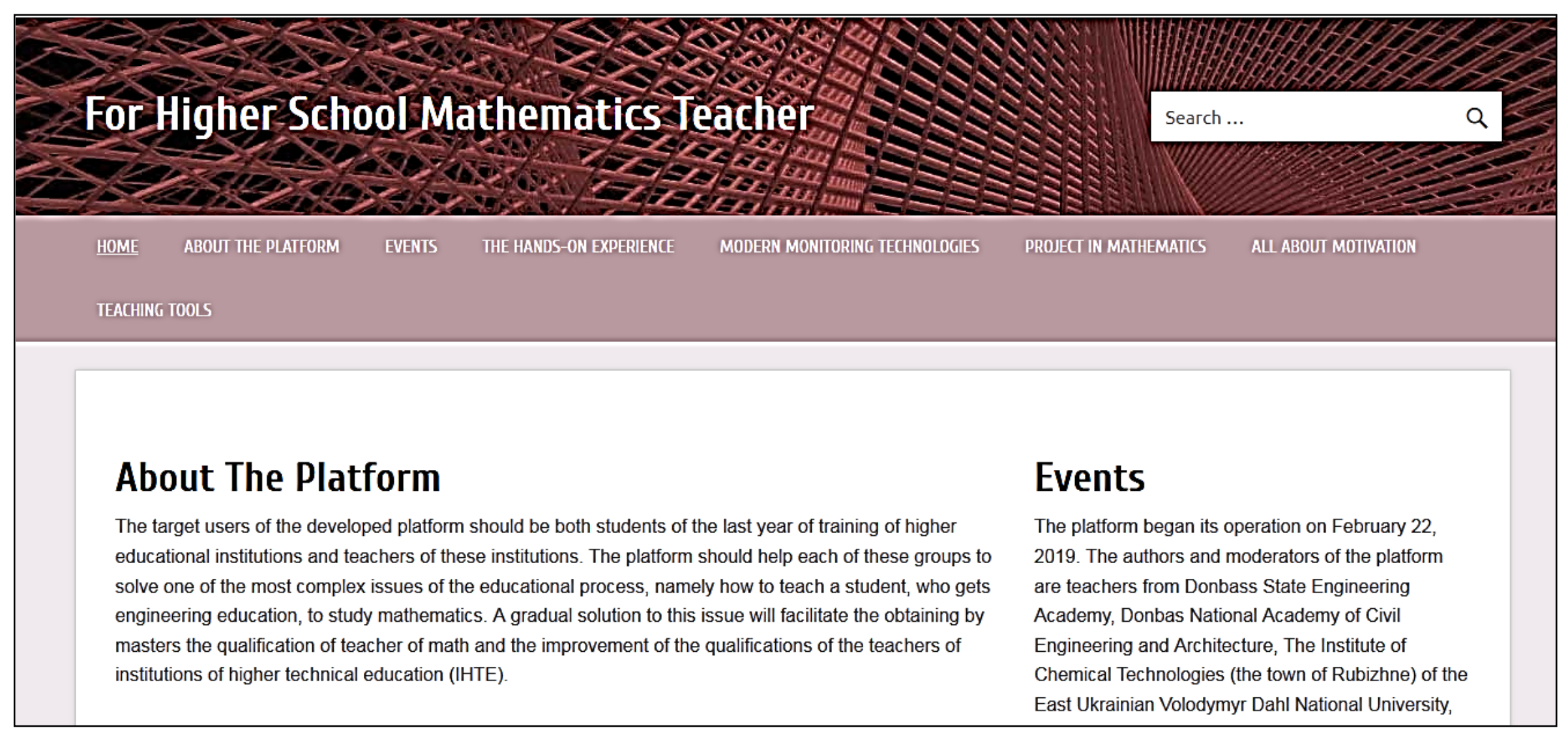

Figure 1. The main page of the 'For Higher School Mathematics Teachers' platform 


\section{Results}

The results of the online questionnaire for mathematics teachers at HTEIs and graduate students at pedagogical and classical HEIs, which was carried out in the course of the ascertaining stage of the experiment, are shown as follows:

The fact that $8 \%$ of the respondents among those interviewed assessed the role of mathematics below 8 points can be seen as to a certain extent negative. That was stated while answering the question "How important is teaching Mathematics in training of future specialists in the technical field. Rate, according to the scale, from 0 to 10 (where 0 is not at all important, 10 is extremely important.)" $76.9 \%$ gave 10 points.

$57.7 \%$ of those interviewed chose the formation of mathematical, logical and system thinking as the main task of mathematical education for Bachelors at HEIs. They noted the importance of developing such mode of thinking for studying complex problems of different nature, methods and approaches to solving theoretical and applied tasks in various subject areas. $15.4 \%$ of the respondents chose the development of the ability to build and study mathematical models and only $11.5 \%$ noted that the main objective of mathematical education is the mastering of the ability to execute high-performance calculations on the basis of cloud services and technologies (Fig. 2).

Most of the teachers, namely $68 \%$, believe that a student "understands the essence of the mathematical notion" if he can apply it while solving tasks in various fields.

An interesting fact is that most teachers underline the experience of engaging technical university students in the creation of projects on higher mathematics. Thus, $53.8 \%$ of the interviewed suppose that such activities primarily focus on the development of research skills, while $26.9 \%$ note that they are aimed at developing key competencies. However, the graduate students basically think the opposite: almost 52\% say that such tasks are aimed at developing key competencies, and only $27.3 \%$ note that they form the research skills.

Moreover, the importance and relevance of this study was determined by the fact that only $52 \%$ of the teachers always demonstrate the connection between higher mathematics and professional disciplines, though $48 \%$ of the respondents have some problems with this (Fig. 3).

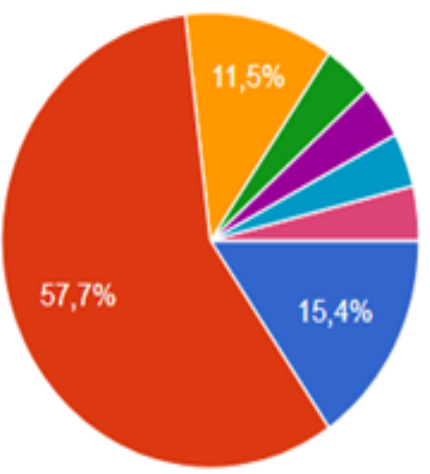

developing the ability to build and study mathematical models;

forming of mathematical, logical and systemic thinking, its application for studying complex problems of different nature, methods and approaches to solving theoretical and applied tasks in various subject areas;

mastering of the ability to perform high-performance calculations on the basis of cloud services and technologies;

Figure 2. Distribution of the respondents according to the main task of mathematical education for undergraduate students at HTEIs

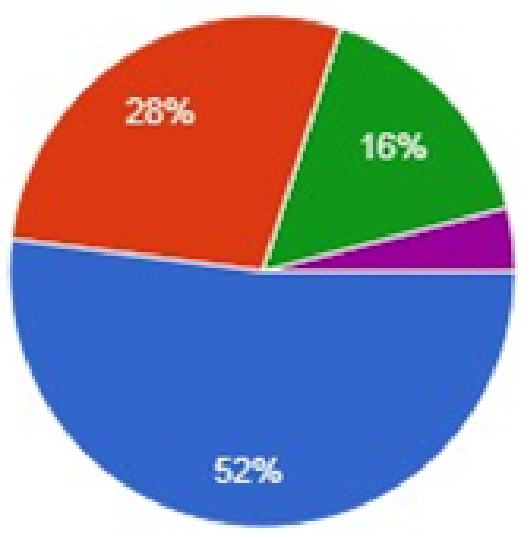

yes, I always understand and demonstrate; not always, sometimes I don't understand; I don't see any connection; I hardly ever demonstrate it.

Figure 3. Distribution of the respondents according to the usage of demonstrating the connection between mathematics and professional disciplines 


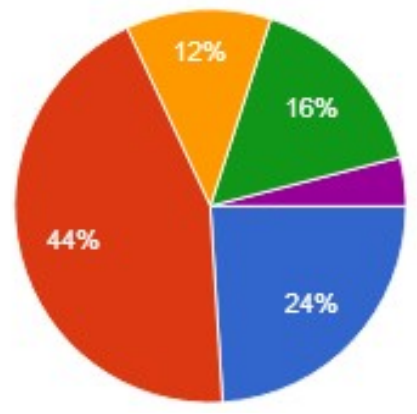

always use, offer the students both the systems of computer-based mathematics and the sites with online calculators that are the most expedient for the topic;

sometimes use, mostly the systems of computer-based mathematics;

sometimes use, mostly cloud online services;

hardly ever use.

Figure 4. Distribution of the respondents according to the priority directions of using computer-based tools

In addition, almost $76 \%$ of the graduate students interviewed state that they have no idea how to prepare for classes on higher mathematics. They do not understand how to demonstrate the expediency of studying one or another topic for students' future professional activities.

Another shortcoming in the teachers' activities comes with the fact that only $24 \%$ of the respondents use the systems of computer-based mathematics, educational sites, and online calculators. $44 \%$ of the teachers mostly use the systems of computer-based mathematics, and only at times free software. $12 \%$ of the respondents use online cloud services (Fig. 4).

Among the graduate students, this indicator differs slightly. $48.5 \%$ of the graduates are ready to offer students both the systems of computer-based mathematics and sites with online calculators. And $33.3 \%$ are ready to work only with the systems of computer-based mathematics.

While giving answers to the questionnaire, the teachers and the graduate students provided recommendations on how to improve the process of training for teaching Mathematics at higher technical education institutions. One of the ways proposed is the development of a training portal for teachers with links to cloud technologies that should be used while teaching Mathematics. This was pointed out by $76 \%$ of the teachers and $81.8 \%$ of the graduate students of pedagogical HEIs. Among the most required components of such a platform, $54.5 \%$ of the graduate students note the need for a practical block containing examples of professionally-oriented or project tasks. $30.3 \%$ of the students emphasize the expediency of considering theoretical material, which would help to understand the connection between Mathematics and the disciplines of the professional field, and $12.1 \%$ emphasize the importance of outlining the ways to increase students' motivation to study Mathematics. In addition, a significant number of the teachers underlined the insufficiency of their knowledge concerning advanced pedagogical practices. The educationalists noted that on occasion they would be willing to take the opportunity to develop creatively and professionally, as well as study foreign experience.

Moreover, among the ways to improve Mathematics teachers' activities, the necessity for cooperation with teachers of special disciplines and coordination of Higher Mathematics syllabus with them was noted.
Thus, the survey conducted confirmed the need to develop a learning platform on which both the teacher and the graduate student would be able to get answers to the questions topical for them. The analysis of the questionnaire results helped to decide upon the platform content.

\section{Discussion}

The analysis of the leading scientists' opinions and the results of the study helped to conclude that the problem of training a Mathematics teacher for higher educational institutions is relevant to many countries around the world. It is accepted by M. Azhar, M. M. Kayani [2], H. C. Çelik and S. Karayaman [6], A. Dorofeev, S. Chirkina, D. Gagloev, T. Savina [8], J. Kilpatrick, J. Swafford, and B. Findell [14], D. Saba [19], A. Tucker, E. Burroughs, A. Hodge [24], N. Volkova [28] etc.

The scientists propose a variety of ways to modernize the vocational and pedagogical training of a higher school teacher.

We agree with the views of A. Dorofeev, S. Chirkina, D. Gagloev, T. Savina [8], which highlight the improvement of a mathematics teacher methodological training of the mathematics teacher at HEI on the basis of multi-component diagnostics of competencies. The researchers developed cognitive, social and humanitarian, operational-activity, research and methodological directions of the model, each component of which corresponds to a certain competency. This approach allows not only evaluating the educational process from different viewpoints with the help of multidimensional vectors, but also correcting its problem areas.

While filling the platform, we will take into account the results of the research performed by the scientists from Chinese mainland and Taiwan, J. Li \& Ch. J Shieh [12], who confirmed the influence of students' internal motivation on their learning efficiency. Namely, they emphasize the effect of multiple goal orientation on learning motivation and learning behaviors. The scientists propose applying the results of their research to professional development as well as teaching and learning improvement. 
The worked-out syllabus for the Master's Degree training programme will take into account the ideas of Pakistan scientists M. Azhar, M. M. Kayani [2], who developed and studied the professional development programme for novice teachers of Punjab. The novice teachers were equipped with the latest training techniques. Training modules were specially designed to promote the novice teachers' professional development. The modules consisted of the materials related to professional development in the area of lesson planning, classroom practices, teaching methodologies, conceptual teaching, activities, educational technology, service related rules and government initiatives. This programme focused on bringing up the novice teachers' capability.

Following American, British and Brazilian scientists, in particular J. Boaler [4], J. Kilpatrick, J. Swafford \& B. Findell [14], M.L. Niess [15], Mary N. Ogawa and Dilmeire S. R. Vosgerau [16], D. Saba [19], A. Tucker, E. Burroughs, A. Hodge [24], we believe that the mathematics teacher professional training program requires reorganization of some existing courses and development of additional courses in the relevant fields. This comes in line with the ideas of J. Ferrini-Mundy from Michigan State University and B. Findell from National Research Council [9]. These scientists believe that prospective higher school mathematics teachers should study the same aspects that students who major in mathematics study, as this will equip them with a coherent picture of the discipline. We also tend to adhere to the ideas of J. Boaler [4], B. Cetinkaya, M. Kertil, A. K. Erbas, H. Korkmaz, C. Alacaci and E. Cakiroglu [7]. The researchers point out that for HTEI mathematics teacher training, it is important to saturate the teaching content with project tasks. R. Powers and W. Blubaugh [17] substantiate the necessity of applying computer-based tools while developing mathematical projects.

Supporting all the above-mentioned and concurring with P. Alves, L. Miranda, C. Morais [1], E. Bender, N. Schaper, M. E. Caspersen, M. Margaritis \& P. Hubwieser [3], S. Lawless, E. Ní Fhloinn, B. Nolan [11], R. Powers and W. Blubaugh [17], we consider the development of the 'For Higher School Mathematics Teacher' online platform to be one of the ways to solve the problems of training and upgrading of Mathematics teachers for technical higher educational institutions. The experience of using such platforms [21] points to their benefits, which come from the focus on an individual.

For further research, the development of a Master's Degree program in 014 'Secondary Education (Mathematics)' specialties is to be considered.

\section{Conclusions}

Thus, the review of the scientific literature and the results of the questionnaire conducted by the higher school lecturers made it possible to ascertain the enormity of the issue of training mathematics teachers for technical higher educational institutions. The respondents' answers helped to determine the ways of solving the issue. $78.9 \%$ of those surveyed pointed out that having an online environment would greatly enhance their professional skills. Keeping up with the respondents' requirements for the accessibility and mobility of such an online environment, we've decided on developing an educational platform.

The basic idea underlying the development of the platform was the collaboration of the experienced higher school teachers, whose joint activities should help address the issues raised by the respondents.

The review of the questionnaire results, the respondents' proposals, and the existing educational resources helped to decide on the sections of the platform. The developed concept of the platform allows for the exchange of teachers' best practices. This is confirmed by the results of OECD surveys in the field of education [30], which emphasize the importance of cooperating of teachers' good practices worldwide in the frameworks of lifelong education.

Among the vectors of further research, the development of a personal e-learning environment for Maths teachers should be noted.

\section{REFERENCES}

[1] Alves, P., Miranda, L., Morais, C. (2017). The Influence of Virtual Learning Environments in Students' Performance. Universal Journal of Educational Research, 5(3), 517-527. doi: 10.13189/ujer.2017.050325

[2] Azhar, M., Kayani, M. M. (2017). Study of the impact of training of novice teachers in the context of transformative learning in Punjab, Pakistan. Advanced Education, 8, 84-91.

[3] Bender, E., Schaper, N., Caspersen, M. E., Margaritis, M., Hubwieser, P. (2016). Identifying and formulating teachers' beliefs and motivational orientations for computer science teacher education. Studies in Higher Education, 41(11), 1958-1973.

[4] Boaler, J. 2002. Mathematical Modeling and New Theories of Learning. Teaching Mathematics and its Applications, 20(3), 121-127.

[5] Brunauer, A. H., Deutsch, T., Cankar, F., (2017). Interconnection of education philosophies and the quality of teaching and learning. Didactica slovenica, 32 (3-4), 30.

[6] Çelik, H.C., Karayaman, S. (2018). Investigating Attitudes of Prospective Mathematics Teachers towards the Use of Mobile Learning at a Higher Learning Institution. Universal Journal of Educational Research, 6(8), 1784 - 1794 doi: 10.13189/ujer.2018.060823

[7] Cetinkaya,B., Kertil, M., Erbas, A. K., Korkmaz, H.,Alacaci, C., Cakiroglu, E. (2016). Pre-service Teachers' Developing Conceptions about the Nature and Pedagogy of Mathematical Modeling in the Context of a Mathematical Modeling Course. Mathematical Thinking and Learning, 
$18(4), 287-314$

[8] Dorofeev, A.V., Chirkina, S.E., Gagloev, D.V., Savina, T.N. (2018). Vector Modeling for Diagnostics of Future Mathematics Teacher Methodical Training in Higher School. EURASIA Journal of Mathematics, Science and Technology Education, 14(12).

[9] Ferrini-Mundy, J., Findell, B. (2001). The Mathematical Education of Prospective Teachers of Secondary School Mathematics: Old Assumptions, New Challenges. CUPM Discussion Papers about Mathematics and the Mathematical Sciences in 2010: What Should Students Know? The Mathematical Association of America. 31-41.

[10] Kyyenko-Romaniuk, L. A., Zayachkovska, L. M. (2012). Information abilities and communication skills as compound of scientifically-methodical teachers competences. Information Technologies and Learning Tools, 2(28).

[11] Lawless,S.,Ní Fhloinn, E., Nolan, B. (2015). Project math's academy: using khan academy's exercise platform as an educational aid in a post-primary mathematics classroom. Online available from https://www.researchgate.net/public ation/276891127 PROJECT MATHS ACADEMY USI NG KHAN ACĀDEMY'S EXERCISE PLATFORM A S_AN_EDUCATIONAL_AID_IN_A_POST-PRIMARY MATHEMATICS_CLASSROŌM

[12] Li, J., Shieh, Ch. J. (2016). A Study on the Effects of Multiple Goal Orientation on Learning Motivation and Learning Behaviors. EURASIA Journal of Mathematics, Science and Technology Education, 12(1), 161-172. https://doi.org/10.12973/eurasia.2016.1221a

[13] Mathematics Standards. Retrieved January 242019 from http://www.corestandards.org/Math/

[14] National Research Council. (2001). Adding it up: Helping children learn mathematics. J. Kilpatrick, J. Swafford, and B. Findell (Eds.). Mathematics Learning Study Committee, Center for Education, Division of Behavioral and Social Sciences and Education. Washington, DC: National Academy Press.

[15] Niess, M. L. (2005). Preparing teachers to teach science and mathematics with technology: Developing a technology pedagogical content knowledge. Teaching and Teacher Education, 21, 509-523.

[16] Ogawa, Mary N., Vosgerau, Dilmeire S. R. (2019). Teacher training of higher education: the role of the institutions. Espacios, 40 (5), 7. Online available from http://www.revi staespacios.com/a19v40n05/19400507.html

[17] Powers, R., Blubaugh, W. (2019). Technology in Mathematics Education: Preparing Teachers for the Future. Contemporary Issues in Technology and Teacher Education. Online available from https://www.citejournal.org/volume5/issue-3-05/mathematics/technology-in-mathematics-educ ation-preparing-teachers-for-the-future/

[18] Quinn, F. (2019). Reform mathematics education is counterproductive for high-tech careers (and it's not the teachers). Online available from https://www.math.vt.edu/ people/quinn/education/techkiller.pdf

[19] Saba, D. (2017). Top 50 Teacher Websites for Seriously Dedicated Educators. Teachers of tomorrow. Online available from https://www.teachersoftomorrow.org/blog/i nsights/teacher-websites

[20] Saqipi, B., Vogrinc, J., (2016). Developing research competence in pre-service teacher education. Didactica slovenica, 31(2), 101.

[21] Six Free Platforms for Teaching Online. Online available from https://oedb.org/ilibrarian/6-free-platforms-teachingonline/

[22] STEM Teacher Training Programs from National Math \& Science Initiative. Online available from https://education. cu-portland.edu/blog/classroom-resources/stem-teacher-tra ining-programs-from-national-math-science-initiative/

[23] The 12 key benefits of learning platforms. How learning platforms support the business of teaching and learning. (2011). Online available from https://www.ttu.ee/public/h/ haridustehnoloogiakeskus/img/12_reasons_web_final-3.pd $\mathrm{f}$

[24] Tucker, A., Burroughs, E., Hodge, A. (2019). A Professional Program for Preparing Future High School Mathematics Teachers. Online available from https://www.maa.org/sites /default/files/HighSchoolMathematicsTeachersPASGRepo rt.pdf

[25] Vasylieva-Khalatnykova, M. (2015). Features of training a teacher for an academic session with students of a higher educational institution. Bulletin of the Taras Shevchenko National University of Kyiv. Pedagogy, 2(2), 16-19.

[26] Vlasenko, K., Chumak, O., Sitak, I. (2019). On Developing the 'For Higher School Mathematics Teacher' leaning platform. The materials of the international scientific and methodological conference 'Problems of Mathematical Education'. April 11-12, 2019; Cherkasy: Cherkasy National University named after Bohdan Khmelnitsky, pp. 40-42, 2019

[27] Vlasenko, K., Sitak, I. (2016). Computer-oriented practical lessons on differential equations: a tutorial for future IT professionals. Kharkiv, Ukraine: Publishing House Leader.

[28] Volkova, N.P., Tarnopolskyi, O.B. (2013). Modeling of professional activity in the teaching of academic disciplines in higher education: monograph. Dnipropetrovsk: Alfred Nobel University.

[29] Yevsiukov, O. (2014). Formation of vocational and pedagogical competence of future teachers of higher agricultural educational institutions. New Collegium, 1, 48-53.

[30] OECD. (2019). Online available from http://www.oecd.org/ 